\title{
Microbiological quality of artisanal and industrial ice creams sold in the south of Rio
}

\section{Grande do Sul}

Qualidade microbiológica de sorvetes artesanais e industrializados vendidos no sull do Rio Grande do Sul

Calidad microbiológica de helados artesanales e industrializados comercializados en el sur de Rio Grande do Sul

Vitor Campos Assumpção de Amarante ORCID: https://orcid.org/0000-0002-0576-0442 Universidade Federal de Pelotas, Brazil E-mail: vitor_amarante@hotmail.com

Bianca Conrad Bohm

ORCID: https://orcid.org/0000-0002-5050-7497 Universidade Federal de Pelotas, Brazil E-mail: biankaBohm@ hotmail.com

Laura Brenner Colling

ORCID: https://orcid.org/0000-0002-2947-706X Universidade Federal de Pelotas, Brazil

E-mail: lbcolling@gmail.com

Caroline Rochenbach

ORCID: https://orcid.org/0000-0002-2948-7954 Universidade Federal de Pelotas, Brazil E-mail: carol.rockembach@hotmail.com

Sergiane Baes Pereira

ORCID: https://orcid.org/0000-0002-5789-6309 Universidade Federal de Pelotas, Brazil E-mail sergiiane@hotmail.com

Fábio Raphael Pascotti Bruhn

ORCID: https://orcid.org/0000-0002-4191-965X Universidade Federal de Pelotas, Brazil E-mail: fabio_rpb@yahoo.com.br

\begin{abstract}
Ice creams have great acceptance and demand by consumers around the world. They are foods obtained through an emulsion of fats and proteins, these ingredients if stored or handled incorrectly can be the source of multiplication of several microorganisms. This work focuses on the microbiological analysis of artesanal and industrial ice cream in two times of the year (winter and summer), performed using the methodology adapted from Silva et al (2010) and the legislative microbiological standards used from RDC No 12 from Anvisa (Brasil, 2001). The main focus was the detection of microorganisms of importance in the food industry, as they are precursors of foodborne diseases epidemics, such as Escherichia Coli, Salmonella, total coliforms, thermotolerant coliforms, molds, yeasts and aerobic mesophilic bacteria. It was observed in the analysis results that all 30 samples showed growth of aerobic mesophilic bacteria, molds and yeasts, that only four (13.33\%) did not have total coliforms and none had Salmonella. There was no great difference between the results of the analyzes of samples collected in the summer and winter, the level of contamination in general was high in samples from both seasons.
\end{abstract}

Keywords: Ice creams; Foodborne diseases; Food safety; Food microbiology; Public health surveillance; Food analyses.

\section{Resumo}

Os sorvetes têm grande aceitação e demanda por consumidores em todo o mundo. São alimentos obtidos através de uma emulsão de gorduras e proteínas, esses ingredientes se armazenados ou manuseados incorretamente podem ser fonte de multiplicação de diversos microrganismos. Este trabalho tem como foco a análise microbiológica de sorvetes artesanais e industriais em duas épocas do ano (inverno e verão), realizada utilizando metodologia adaptada de Silva et al (2010) e as normas microbiológicas legislativas utilizadas da RDC n 12 da Anvisa (Brasil, 2001). O foco principal foi a detecção de microrganismos de importância na indústria de alimentos, por serem precursores de epidemias de doenças de origem alimentar como Escherichia Coli, Salmonella, coliformes totais, coliformes termotolerantes, bolores, leveduras e bactérias aeróbias mesófilas. Observou-se nos resultados das análises que todas 
as 30 amostras apresentaram crescimento de bactérias aeróbias mesófilas, bolores e leveduras, sendo que apenas quatro (13,33\%) não apresentaram coliformes totais e nenhuma apresentou Salmonella. Não houve grande diferença entre os resultados das análises das amostras coletadas no verão e no inverno, o nível de contaminação em geral foi elevado nas amostras das duas estações.

Palavras-chave: Sorvetes; Doenças transmitidas por alimentos; Segurança alimentar; Microbiologia de alimentos; Vigilância em saúde pública; Análises de alimentos.

\section{Resumen}

Los helados son ampliamente aceptados y demandados por consumidores en todo el mundo. Son alimentos obtenidos a través de una emulsión de grasas y proteínas, estos ingredientes si se almacenan o manipulan incorrectamente pueden ser fuente de multiplicación de varios microorganismos. Este trabajo se centra en el análisis microbiológico del helado artesanal e industrial en dos épocas del año (invierno y verano), realizado con metodología adaptada de Silva et al (2010) y los estándares microbiológicos legislativos utilizados en el RDC nº 12 de Anvisa (Brasil, 2001). El foco principal fue la detección de microorganismos de importancia en la industria alimentaria, ya que son precursores de epidemias de enfermedades transmitidas por alimentos como Escherichia Coli, Salmonella, coliformes totales, coliformes termotolerantes, mohos, levaduras y bacterias aerobias mesófilas. Se observó en los resultados del análisis que las 30 muestras presentaron crecimiento de bacterias mesófilas aerobias, mohos y levaduras, siendo que solo cuatro $(13,33 \%)$ no presentaron coliformes totales y ninguna presentó Salmonella. No hubo gran diferencia entre los resultados del análisis de las muestras recolectadas en el verano y en el invierno, el nivel de contaminación en general fue alto en las muestras de las dos temporadas.

Palabras clave: Helados; Enfermedades transmitidas por los alimentos; Seguridad alimentaria; Microbiología alimentaria; Vigilancia de la salud pública; Análisis de alimentos.

\section{Introduction}

Being one of the most accepted dairy products and sought after by consumers around the world, ice cream is a product in which good production and handling practices are increasingly required. The lack of hygiene in food handling is one of the most important factors when it comes to food security. Ice cream from its production to consumption can suffer contamination due to direct and/or indirect contact with pathogens, which can cause the spread of several foodborne diseases (Souza, et al., 2017).

According to the Brazilian Association of Industries and the Ice Cream Sector (ABIS) the average worldwide consumption per capita is 5.3 liters per inhabitant / year and the average in Brazil is 5.44 liters per inhabitant / year (ABIS, 2018). In this way, it is possible to observe the importance of strict microbiological control in all stages of production and commercialization of ice cream, with emphasis on the control of storage temperature (Brasil, 2003).

Outbreaks of foodborne diseases (FBD) are usually caused by several hygienic-sanitary factors that are not respected, including: inadequate refrigeration, food preparation with large time spans between production processes, insufficient thermal processing, infected handlers, contamination between basic food components, use of unregulated products and incorrect hygiene of utensils and hands of food handlers (Abreu, et al., 2011). Data from the Ministry of Health indicate that between 2000 and 2017, 12,660 outbreaks of FBD were reported in Brazil, affecting 239,164 people and leading to death 186. The South $(33.7 \%)$ and Southeast $(39.1 \%)$ regions of Brazil represent the largest share of reported outbreaks in the country (Brasil, 2018).

When subjected to microbiological tests, samples of ice cream have limits established for the indicative sample or representative sample, in order to prove whether the sample or even the product batch is fit for human consumption. According to the National Health Surveillance Agency (Anvisa) in RDC 12/01, there is no tolerance for Salmonella sp / 25 for an indicative sample. The tolerance for an indicative sample of coliforms at $45^{\circ} \mathrm{C} / \mathrm{g}$ is $5 \times 10 \mathrm{MPN} / \mathrm{mL}$ (Brasil, 2001). To meet such limits imposed by legislation, production processes with high hygienic-sanitary control must be adopted, always in search of the application of good manufacturing, storage and monitoring practices (Weber \& Carrijo, 2018).

Although at a global level there is an increase in awareness about FBD and their risks to public health and socioeconomic development, investments and investigation of outbreaks resulting from the consumption of inappropriate food are 
still low, especially in developing countries such as Brazil, where detailed epidemiological data on this topic are lacking (World Health Organization [WHO], 2015). In view of this, the objective of the present work is to evaluate the microbiological quality of milk-based ice creams, manufactured industrially and artisanal in the city of Pelotas / RS.

It is important to highlight that conducting research on the standard of food quality is a way to prevent outbreaks of FBD. Alert the community to the occurrence of such disease, encourage the search for medical care after the consumption of any contaminated food or water, sensitize health professionals of the importance of notifying when they suspect an FBD case, so that the surveillance agencies can investigate the suspected cases and generate information so that decision makers are adequately informed about the economic and social impacts of these diseases, as this is the only way to establish efficient control strategies.

\section{Methodology}

An epidemiological study was carried out by collecting samples of ice cream sold at different points in the municipality of Pelotas, Rio Grande do Sul. The city of Pelotas (Latitude: -31.776, Longitude: -52.3594 31 ${ }^{\circ} 46^{\prime} 34^{\prime \prime}$ South, 52 $\circ 21^{\prime} 34$ " West), is located in the extreme south of Brazil, just seven meters above sea level and is the third largest city in the state of Rio Grande do Sul. Its estimated population is 342,405 thousand inhabitants, with an area of $1,609 \mathrm{~km}^{2}$ and the prevailing climate in the city is humid subtropical (IBGE, 2019).

A total of 18 random points of sale of ice cream were selected (Figure 1) where samples of ice cream type express (Italian) and buffet type (self service) were collected, with the repetition of collections in these places at different seasons of the year ( summer and winter). In total, 30 samples of ice cream, 15 samples of buffet and 15 samples of express ice cream were analyzed at two times of the year, summer (16) and winter (14). The 15 analyzed samples of express ice cream were acquired in nine commercial establishments, seven samples were collected in the summer and eight in the winter. Of the nine establishments, six were collected at both times of the year, three establishments only sell the product in the summer, thus preventing collection in the winter. 15 samples of self-service buffet ice cream were collected, these samples were acquired in nine ice cream parlors located in the city center of Pelotas, the project provided for the collection of ice cream at two times of the year, summer and winter, however, only six ice cream parlors they work all year round, so in three establishments it was not possible to carry out the winter collection. Of the total samples, nine were collected in the summer and six in the winter. The project prioritized collecting samples from the same establishments at both times of the year, in order to compare the quality of the product in the period of greatest commercialization (summer) and in the period when the demand for consumption is lowest (winter). 
Figure 1. Selected ice cream parlors in the city of Pelotas - RS.
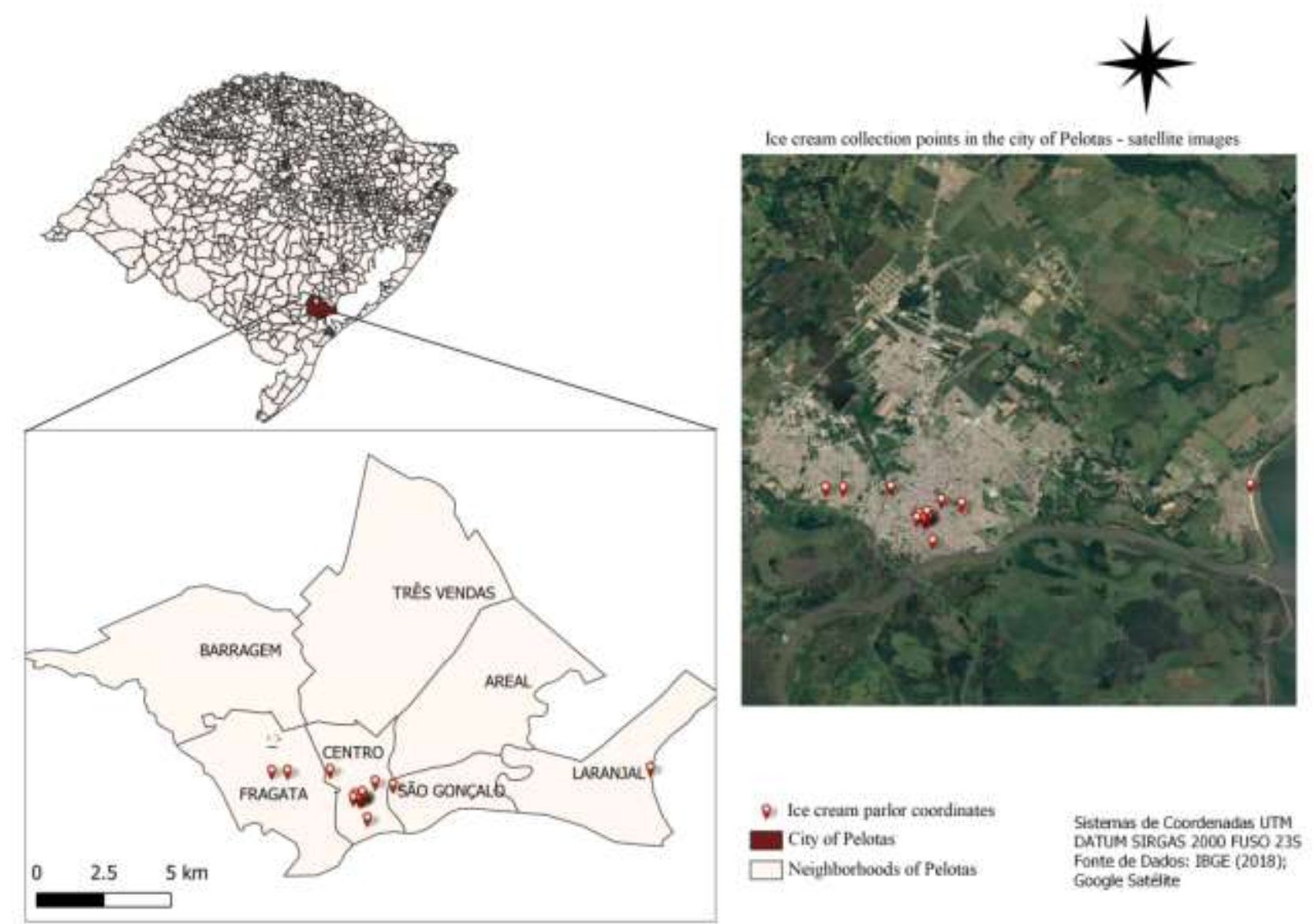

Fonte: Autores.

After acquisition, the samples were transferred to a previously sterilized glass bottle and were transported in an isothermal box to the Laboratory of the Zoonosis Control Center at the Federal University of Pelotas (CCZ / UFPel) where the analyzes were performed. Microbiological analysis were performed using the methodology adapted from Silva et al (2010) and the legislative microbiological standards used were from RDC No. 12 from Anvisa (Brasil, 2001).

To quantify the total and thermotolerant coliforms in the samples, the most probable number technique (MPN) was used, according to the American Public Association (APHA), described by Silva (2010). After homogenization of the ice creams, aseptically, $25 \mathrm{~mL}$ of each sample was transferred to an Erlenmeyer flask containing $225 \mathrm{~mL}$ of $0.1 \%$ peptone water and homogenized (10: 1 or 10-1 dilution). From this dilution, subsequent dilutions (10-2 and 10-3) were performed. Aliquots of 1 $\mathrm{mL}$ were transferred to a series of three tubes, by dilution, containing $10 \mathrm{~mL}$ of Lauryl Sulfate Tryptose Broth (LST) with inverted Durhan tubes. The observation of growth with gas production, resulting from the fermentation of lactose present in the culture medium after 24 to 48 hours of incubation in a bacteriological oven at a temperature of 35 to $37^{\circ} \mathrm{C}$ is considered suspicious or presumptive of the presence of coliforms. The tubes that showed gas formation inside the Durhan tube and the turbidity of the broth (LST), have aliquots sown in tubes containing $7 \mathrm{~mL}$ of Brilliant Green Broth $2 \%$ (BG) containing inverted Durhan tubes for the growth of total coliforms. The same occurs for counting thermotolerant coliforms, where the positive broth tubes (LST) were transferred to tubes containing Escherichia coli broth (EC) and placed in a bacteriological oven at a temperature of 44.5 to $45^{\circ} \mathrm{C}$ for 24 hours. The production of gas inside Durhan's tubes testifies to the positivity of these tests. EC tubes that are positive are suspected for the presence of E. coli. For the isolation of this microorganism, aliquots of 
this culture medium were used to sow in Petri dishes containing culture medium Methylene Blue Eosin Agar (EMB) and subsequently incubated at 35 to $37^{\circ} \mathrm{C}$ for 24 hours. The growth of colonies with bright green color on the EMB plates is characteristic of thermotolerant bacteria, the next step for the confirmation of e.coli would be the biochemical battery that was not performed at the moment. The bacteria that showed the characteristic color were frozen for further analysis. The results were analyzed using the MPN table.

The standard aerobic mesophil count was performed using the APHA total aerobic mesophile plate count method, described by Silva et al (2010). Initially, $1 \mathrm{~mL}$ of the different dilutions was inoculated, using the Pour plate Method, using the standard counting agar (PCA). The inoculated plates were incubated in a bacteriological oven at a temperature of 35 to $37^{\circ} \mathrm{C} /$ 48 hours. After this period, microorganisms were counted and the total colonies were multiplied by the inverse of the corresponding dilution. The results are expressed in colony forming units per milliliter of product analyzed (CFU / $\mathrm{mL})$.

The analysis of molds and yeasts were performed using the method of total counting of molds and yeasts in plates, according to APHA described by Silva et al (2010). The samples were first subjected to decimal dilutions in $0.1 \%$ peptone water. The method used in this segment was surface plating on Potato Dextrose Agar (PDA). $0.1 \mathrm{~mL}$ of the sample was inoculated in the respective dilutions and incubated at $25^{\circ} \mathrm{C}$ for a period of 5 days. To calculate the number of colony forming units per milliliter $(\mathrm{CFU} / \mathrm{mL})$, the number of colonies was multiplied by the inoculated volume $(0.1 \mathrm{~mL})$ and by the inverse of the corresponding dilution.

For the research of Salmonella spp, the same procedure already described in the analysis of the other microorganisms was adopted, however, $25 \mathrm{~mL}$ of each sample was used, being homogenized in $225 \mathrm{~mL}$ of $1 \%$ buffered water and incubated at 35 to $37^{\circ} \mathrm{C}$ for 24 hours. After the incubation period, $1 \mathrm{ml}$ of each sample diluted in $1 \%$ buffered water was transferred to a test tube containing $10 \mathrm{ml}$ of Tetrathionate Broth (TT) (previously, $0.1 \mathrm{ml}$ of Bright Green and 0,2 $\mathrm{mL}$ of iodine) and $0.1 \mathrm{~mL}$ into a test tube containing $10 \mathrm{~mL}$ of Rappaport Vassiliadis Broth (RV) and were incubated at $41^{\circ} \mathrm{C}$ for 24 hours. After the incubation period, an elevation of the Tetrathionate Broth was sown using the depletion technique for a petri dish containing Xylose Lysine Deoxycholate Agar (XLD) and again a culture lift for a petri dish containing Hectoen Enteric Agar (HE). The same procedure is performed with the culture in Rappaport Vassiliadis Broth. Both plates were incubated at 35 to $37^{\circ} \mathrm{C}$ for 24 hours. Plates containing Xylose Lysine Deoxycholate Agar, in the presence of Salmonella, have pink or black colonies, while plaques containing Hectoen Enteric Agar (HE) have blue-green to blue colonies or may be black or completely black.

\section{Results}

It was found that $11.1 \%(1 / 9)$ of the express type ice cream outlets were outside the law, but none of them sold ice cream with the presence of Salmonella spp (Table 1). 
Table 1. Results of the microbiological analysis of express ice cream (Italian) sold in establishments in the city of Pelotas-RS, at two times of the year.

\begin{tabular}{|c|c|c|c|c|c|c|c|}
\hline $\begin{array}{l}\text { Ice cream } \\
\text { parlor }\end{array}$ & $\begin{array}{l}\text { Time of the } \\
\text { year }\end{array}$ & $\begin{array}{l}\text { Meets brazilian } \\
\text { legislation }\end{array}$ & $\begin{array}{c}\text { Total } \\
\text { coliforms } \\
(\mathrm{MPN} / \mathrm{g})\end{array}$ & $\begin{array}{l}\text { Thermotolerant } \\
\text { coliforms (MPN/g) }\end{array}$ & $\begin{array}{l}\text { Mesophilic } \\
\text { heterotrophic } \\
\text { bacterias } \\
(\mathrm{CFU} / \mathrm{g})\end{array}$ & $\begin{array}{c}\text { Molds and yeasts } \\
\text { (CFU/g) }\end{array}$ & Salmonella \\
\hline 1 & Summer & Yes & 460 & 43 & $66 \times 10^{-3}$ & $114 \times 10^{-1}$ & Negative \\
\hline 1 & Winter & Yes & 43 & 0 & $81 \times 10^{-3}$ & $840 \times 10^{-3}$ & Negative \\
\hline 2 & Summer & Yes & 1100 & 43 & $35 \times 10^{-3}$ & Incalculable & Negative \\
\hline 2 & Winter & Yes & 1100 & 0 & $160 \times 10^{-1}$ & $259 \times 10^{-2}$ & Negative \\
\hline 3 & Summer & Yes & 240 & 9 & $282 \times 10^{-2}$ & Incalculable & Negative \\
\hline 4 & Winter & No & 1100 & 210 & $315 \times 10^{-2}$ & Incalculable & Negative \\
\hline 4 & Summer & Yes & 460 & 0 & Incalculable & $38,4 \times 10^{-3}$ & Negative \\
\hline 5 & Winter & Yes & 43 & 0 & $2 \times 10^{-3}$ & $27 \times 10^{-4}$ & Negative \\
\hline 5 & Summer & Yes & 43 & 0 & $9 \times 10^{-2}$ & $24 \times 10^{-2}$ & Negative \\
\hline 6 & Summer & Yes & 20 & 0 & $4 \times 10_{-4}^{-4}$ & $17 \times 10^{-4}$ & Negative \\
\hline 6 & Summer & Yes & 43 & 0 & Incalculable & $91 \times 10^{-3}$ & Negative \\
\hline 7 & Winter & Yes & 9 & 0 & $1 \times 10^{-4}$ & $26 \times 10^{-4}$ & Negative \\
\hline 7 & Summer & Yes & 0 & 0 & $540 \times 10^{-2}$ & $69 \times 10^{-2}$ & Negative \\
\hline 8 & Winter & Yes & 0 & 0 & $15 \times 10^{-1}$ & $27 \times 10^{-1}$ & Negative \\
\hline 9 & Summer & Yes & 0 & 0 & $20 \times 10^{-1}$ & $12 \times 10^{-1}$ & Negative \\
\hline
\end{tabular}

Fonte: Autores.

The seven samples collected in the summer had growth of mesophilic bacteria, molds and yeasts and total coliforms, four of these samples $(57.2 \%)$ had thermotolerant coliforms, however, only in the sample of establishment " 4 " the value was outside the legislative standards, making the product unfit for consumption.

The eight samples collected in winter also showed growth of mesophilic bacteria, molds and yeasts, five of them $(62.5 \%)$ had growth of total coliforms and no sample showed growth of thermotolerant coliforms. No Salmonella was found in all samples at both times of the year.

The microbiological quality of the buffet ice creams was also analyzed, the results of the analyzes are described in Table 2. Among the ice cream parlors, $44.4 \%$ sell products outside the microbiological specifications provided for in Brazilian legislation.

It is possible to point out that there was no great difference between the results of the analyzes of samples collected in summer and winter, the level of contamination in general was high in samples from both seasons. 
Table 2. Results of the microbiological analysis of buffet ice cream sold in establishments in the city of Pelotas - RS, at two times of the year.

\begin{tabular}{|c|c|c|c|c|c|c|c|}
\hline $\begin{array}{l}\text { Ice cream } \\
\text { parlor }\end{array}$ & $\begin{array}{l}\text { Time of the } \\
\text { year }\end{array}$ & $\begin{array}{c}\text { Meets } \\
\text { brazilian } \\
\text { legislation }\end{array}$ & $\begin{array}{c}\text { Total } \\
\text { coliforms } \\
\text { (MPN/g) }\end{array}$ & $\begin{array}{l}\text { Thermotolerant } \\
\text { coliforms (MPN/g) }\end{array}$ & $\begin{array}{c}\text { Mesophilic } \\
\text { heterotrophic } \\
\text { bacterias } \\
(\mathrm{CFU} / \mathrm{g})\end{array}$ & $\begin{array}{c}\text { Molds and yeasts } \\
\text { (CFU/g) }\end{array}$ & Salmonella \\
\hline 1 & Summer & Yes & 43 & 43 & $188 \times 10^{-2}$ & $67 \times 10^{-1}$ & Negative \\
\hline 1 & Winter & Yes & 150 & 0 & $209 \times 10^{-2}$ & $135 \times 10^{-2}$ & Negative \\
\hline 2 & Summer & Yes & 93 & 0 & $164 \times 10^{-2}$ & $154 \times 10^{-1}$ & Negative \\
\hline 2 & Winter & Yes & 1100 & 0 & Incalculable & $35,2 \times 10^{-2}$ & Negative \\
\hline 3 & Summer & No & $>1100$ & $>1100$ & $188 \times 10^{-2}$ & $22 \times 10^{-1}$ & Negative \\
\hline 3 & Winter & Yes & 240 & 7 & $183 \times 10^{-1}$ & $36 \times 10^{-2}$ & Negative \\
\hline 4 & Summer & Yes & $>1100$ & 0 & $158 \times 10^{-2}$ & $39 \times 10^{-1}$ & Negative \\
\hline 4 & Winter & No & 1100 & 75 & $210 \times 10^{-1}$ & $26 \times 10^{-1}$ & Negative \\
\hline 5 & Summer & Yes & $>1100$ & 21 & $56 \times 10^{-2}$ & $490 \times 10^{-1}$ & Negative \\
\hline 6 & Summer & No & 75 & 75 & $142 \times 10^{-2}$ & $166 \times 10^{-1}$ & Negative \\
\hline 7 & Summer & No & $>1100$ & 290 & $109 \times 10^{-2}$ & $129 \times 10^{-1}$ & Negative \\
\hline 7 & Summer & Yes & 0 & 0 & $247 \times 10^{-2}$ & $76 \times 10^{-2}$ & Negative \\
\hline 8 & Summer & Yes & 93 & 0 & $303 \times 10^{-2}$ & $560 \times 10^{-3}$ & Negative \\
\hline 8 & Winter & Yes & 1100 & 0 & $157,5 \times 10^{-2}$ & $63 \times 10^{-2}$ & Negative \\
\hline 9 & Summer & Yes & 23 & 0 & $336 \times 10^{-2}$ & $57 \times 10^{-2}$ & Negative \\
\hline
\end{tabular}

Fonte: Autores.

The nine samples collected in the summer showed growth of mesophilic bacteria, molds and yeasts and total coliforms. Of the nine samples, five (55.6\%) showed a growth in thermotolerant coliforms, and in establishments "3", "6" and "7" were outside the limits allowed by brazilian legislation.

In the winter, six samples were collected, all of which showed growth of mesophilic bacteria, molds and yeasts. The presence of total coliforms was verified in five of these samples (83.3\%) and in two samples there was the presence of thermotolerant coliforms, and the sample from establishment "4" was outside the legislative standards. In no sample was detected the presence of Salmonella.

It is important to highlight that in some establishments it was not possible to carry out the collection in some period for various reasons, in some cases the establishments did not open at the time and in others the establishment closed its activities.

\section{Discussion}

It was observed in the analysis results that all 30 samples showed growth of aerobic mesophilic bacteria, molds and yeasts, and that only four (13.33\%) did not have total coliforms. A high frequency of aerobic mesophiles indicates poor hygienic-sanitary conditions of the ice cream, preparation and/or storage locations, indicating problems in food handling 
(Pazianotti, et al., 2011; Silva, et al., 2010). The presence of yeasts and mold is indicative of poor sanitary practices in the manufacture and/or packaging of food products (Junqueira, et al., 2012). Barbosa et al (2010) declares that Cândido Tostes Institution (EPAMIG) determined that the counts of molds and yeasts for milk and dairy products such as ice cream must be less than $200 \mathrm{CFU} / \mathrm{g}$ to be considered satisfactory, therefore, only three samples of ice cream of the express type had a higher count than the determined. The presence of total coliforms in food represents contamination in post-processing, usually from employees who have not done the correct hand hygiene or contaminated utensils that ended up coming into contact with the food in production or storage (Sales, et al., 2016).

Infections by Salmonella spp have gained attention and care at a global level in recent years for referring to the bacterium that causes most FBD in the world, responsible for an often serious toxi-infection, which can lead the infected individual to death (Freire, 2018; Silva, et al., 2019). Considering its importance, the present study verified the absence of this microorganism in the samples, therefore, it is a satisfactory result, considering the current legislation and the fact that this microorganism can develop even in low temperatures, as well as it can indicate that machinery used in production of these ice creams is regularly cleaned and their temperatures are regulated and that the water used in these establishments is of high quality and does not contain contamination by this microorganism (Freire, 2018; Paiva, et al., 2016).

The presence of thermotolerant coliforms in food samples indicates contamination of faecal origin, pointing to poor hygienic-sanitary conditions in the facilities where they are manufactured and sold (Rizzato-Benato \& Gallo, 2017; Silva, et al., 2019; Silva \& Martins, 2010). In total, five samples were presented outside the legislative standards determined by Anvisa (Brasil, 2001), thus, four establishments were selling ice cream unfit for consumption, putting consumers at risk.

The Centers for Disease Control and Prevention, estimates that about 17\% of americans get sick every year, 128,000 are hospitalized and 3,000 die from foodborne diseases (Centers for Disease Control and Prevention [CDC], 2018). In Brazil, the epidemiological profile of these diseases is still little known and investigated, since the coverage of epidemiological and sanitary surveillance is not complete, therefore, few states and municipalities are able to collect data on outbreaks, risk factors and food of greater potential risk. Despite this, it is estimated that there are around 700 outbreaks of FBD each year in Brazil (Brasil, 2017; Dias, et al., 2011).

As it is an important public health issue, the hygienic-sanitary control of food is considered an attribution of the veterinarian, who is part of this dynamic as a fundamental agent in obtaining quality food products of animal origin, condemning inappropriate foods for human and animal consumption, investigating the sanitary conditions of commercial establishments, as well as working in the prevention and notification of outbreaks of FBD, being activities provided for in law 8080/1990 in article 6 that regulates SUS actions throughout the national territory (Brasil, 1990; Prestes, 2016; Santos, et al., 2007; Vasconcellos \& Sangioni, 2017). In view of this scenario, it is highlighted that although access to health is a social right and is constitutionally guaranteed through the Unified Health System (Brasil, 1988), the search for care today is still a challenge for this system and, consequently, presents itself as a problem for epidemiological and health surveillance that are part of SUS (Osorio, 2011). Underreporting, however declining, is still one of the major factors of this problem, together with the lack or low investigation contribute to a scenario of low influx of information in the surveillance spectrum, which ends up creating a vicious cycle because the less notifications are made, less is the perception of the problem and, consequently, public investments in sanitary and epidemiological surveillance systems are increasingly scarce, which causes their deterioration, as well as a growing neglect in investigations, again generating a decrease in reports of outbreaks of these diseases (Van Amson, et al., 2006).

The identification and investigation of food-borne outbreaks are essential in the prevention and control of DTAs, therefore, outbreaks without a defined etiological agent may be related to the lack of investments in organs responsible for 
epidemiological surveillance, laboratory tests without precision or quality, delayed notifications or even the absence of sampling for testing.

Thus, the number of reported outbreaks is related to the level of implementation of the National Epidemiological Surveillance System for Foodborne Diseases (VE-DTA) in the municipalities (Barbosa, et al., 2010). In Rio Grande do Sul, the bodies responsible for implementing and regulating the notification system for FBD are the 19 Regional Health Coordinators (RHC) that cover the entire state (Brasil, 2014). A study (Dos Santos, 2013) by the State Health Surveillance Center of Rio Grande do Sul (CEVS) using questionnaires applied to those responsible for the agencies, found that in 18 RHC were failures and difficulties experienced in the epidemiological surveillance of FBD. The results obtained point to factors such as the lack of human resources, present in $61.1 \%$, underreporting (50.0\%), lack of training (38.9\%), investigations of outbreaks (38.9\%) and notifications (16,7\%). In 2014, 128 outbreaks of DTAs were reported in the state, with only $55(42.96 \%)$ of these cases investigated, only 29 (22.65\%) confirmed and only 25 (19.53\%) the pathogenic agent was identified. In view of the relevance in identifying the agent that causes FBD, as done in the present study, it is important to understand how and in what part of the production process these agents end up contaminating food (Silva, et al., 2010).

\section{Final Considerations}

In the present study, large amounts of aerobic mesophiles, total coliforms, molds and yeasts were counted in various ice cream samples, which are microorganisms that are not covered by microbiological limits for ice cream under current brazilian legislation, thus configuring a problem to be discussed and resolved at the national level, as these agents may pose a danger to public health.

Based on what was exposed in this study, it is possible to affirm that the veterinary medical professional is an important agent in sanitary and epidemiological surveillance, being of great relevance for guaranteeing quality food products that do not present risks to public health. It is pointed out that other studies carried out by veterinarians and other health professionals in this same field of research would be of great value for exposing the theme of veterinary public health and for the training of future health professionals.

\section{References}

Associação Brasileira das Indústrias e do Setor de Sorvetes (ABIS). (2018). Clash discute a importância da comunicação para o setor de sorvetes no Brasil. http://www.feirasdobrasil.com.br/revista.asp?area=noticias\&codigo=62431.

Abreu, E. S., Medeiros, F. S., \& Santos, D. A. (2011). Análise Microbiológica De Mãos De Manipuladores De Alimentos Do Município De Santo André. Revista Univap, 17 (30). http://dx.doi.org/10.18066/revunivap.v17i30.24

Barbosa, A. S., Araujo, A. S., Martins, W. F., Rodrigues, M. S. A., \& Florentino, E. R. (2010). Avaliação Do Perfil Microbiológico De Gelados-Comestíveis Comercializado Em Campina Grande-Pb. Revista Verde de Agroecologia e Desenvolvimento Sustentável. 5(3), 68-79.

Brasil, (1988). Constituição da República Federativa do Brasil: Senado Federal.

Centers for Disease Control and Prevention (CDC), U.S. Department of Health \& Human Services. (2018). CDC and Food Safety. https://www.cdc.gov/foodsafety/cdc-and-food-safety.html.

Dias, R. S., Leal Bernades, A. F., \& Zuccoli, P. C. (2011). A importância do processo de investigação na elucidação de surtos de Doenças Transmitidas por Alimentos (DTA). NBC-Periódico Científico do Núcleo de Biociências, 1(2), 17-23. http://dx.doi.org/10.15601/2238-1945/pcnb.v1n2p17-23.

Dos Santos, D. V., Figuereido, D. M. S., Santini, A. P., Ramos, L. S., \& Saccol, A. L. F. (2013). Implantação e Situação do Sistema de Notificações das Doenças Transmitidas por Alimentos no Estado do Rio Grande do Sul. Boletim Epidemiológico. 15(3).

Freire, D. F. L. (2018). Doenças transmitidas por alimentos, tendo como agente causal a Salmonella SPP: uma revisão. Universidade Federal de Campina Grande, Campina Grande.

Instituto Brasileiro de Geografia e Estatística (IBGE). (2019). Censo demográfico: Pelotas, 2019.

Junqueira S. F., Souza A. O., Reis P. M. C. L., Mascarenhas R. J., \& Yamamoto M. (2012). Contagem Microbiológica De Gelado Comestível De Fruta Adicionado De Ervas. Vii Connepi-Congresso Norte Nordeste de Pesquisa e Inovação. 
Ministério da Saúde. (1990). Lei $\mathrm{n}^{\circ} 8.080$ de 19 de setembro de 1990. Dispõe sobre as condições para a promoção, proteção e recuperação da saúde, a organização e o funcionamento dos serviços correspondentes e dá outras providências. Diário Oficial da União.

Ministério da Saúde. (2001). Resolução RDC nº 12, de 02 de janeiro de 2001.

Ministério da Saúde. (2003). Resolução RDC nº 267, de 25 de setembro de 2003.

Ministério da Saúde. (2017). Doenças Transmitidas por Alimentos. https://antigo.saude.gov.br/saude-de-a-z/doencas-transmitidas-por-alimentos.

Ministério da Saúde. (2018). Surtos de doenças transmitidas por alimentos no Brasil. http://portalms.saude.gov.br/images/pdf/2018/julho/02/ApresentacaoSurtos-DTA-Junho-2018.pdf.

Osorio R. G., Servo L. M. S., \& Piola, S. F. (2011). Necessidade de saúde insatisfeita no Brasil: uma investigação sobre a não procura de atendimento. Ciência \& Saúde Coletiva, (16), 3741-3754.

Paiva Y. F., Silva E. V., Araújo A. S., Azevedo P. T. M., \& Sousa T. C. A. (2016). Condições higiênico-sanitárias de sorvetes do tipo italiano, soft, comercializados em Pombal, Paraíba. Revista Verde de Agroecologia e Desenvolvimento Sustentável, 11(3), 75-79. http://dx.doi.org/10.18378/rvads.v11i3.4389

Pazianotti, L., Bosso, A. A., Cardoso, S., Costa, M. R., \& Sivieri, K. (2010). Características microbiológicas e físico-químicas de sorvetes artesanais e industriais comercializados na região de Arapongas-PR. Revista do Instituto de Laticínios Cândido Tostes. 65(377), 15-20. https://doi.org/10.14295/2238-6416.v65i377.145

Prestes, R. S. (2016). Atuação do médico veterinário no sistema único de saúde: percepção dos acadêmicos de medicina veterinária. Universidade Federal do Pampa, Uruguaiana.

Rizzo-Benato, R. T., \& Gallo, C. R. (2017). Comparação da eficiência dos caldos Escherichia coli e caldo verde brilhante lactose bile na enumeração de coliformes termotolerantes em leite e sorvete de massa. Revista do Instituto Adolfo Lutz, 66(1), 18-25.

Secretaria Estadual de Saúde do Rio Grande do Sul. (2014). Organização da Saúde no Território Gaúcho - Município, CRS, Região de Saúde, Macrorregião e Coredes. https://saude.rs.gov.br/upload/arquivos/carga20190107/29150758-municipio-regiao-crs-macro-corede.pdf.

Sales, W. B., Caveião, C., Grillo, F. R., Ravazzani, E. D. A., \& Vasco, J. F. M. (2016). Presença de coliformes totais e termotolerantes em sucos de frutas cítricas. Revista Saúde e Desenvolvimento, 9(5), 106-118.

Santos, L. M., Rocha, J. R., \& Casale, D. S. (2007). Importância do médico veterinário na produção de alimento de origem animal, para a sociedade. revisão de literatura. Revista científica eletrônica de medicina veterinária, 4(8).

http://dx.doi.org/10.15601/2238-1945/pcnb.v1n2p17-23

Silva, A. J. H., Anjos, C. P., Nogueira, L. S., Ribeiro, A. C. R., \& Fraga, E. G. S. (2019). Salmonella spp. um agente patogênico veiculado em alimentos. Encontro de Extensão, Docência e Iniciação Científica (EEDIC). 5(1).

Silva, E. P., Bergamini, A. M. M., \& Oliveira, M. A. (2010). Alimentos e agentes etiológicos envolvidos em toxinfecções na região de Ribeirão Preto, SP, Brasil: 2005 a 2008. BEPA. Boletim Epidemiológico Paulista (Online), 7(77), 04-10.

Silva, M. F. O., \& Martins, E. S. (2010). Qualidade microbiológica de sorvetes comercializados em Frutal, Minas Gerais. Revista Verde de Agroecologia e Desenvolvimento Sustentável, 14(1), 128-133. http://dx.doi.org/10.18378/rvads.v14i1.5800

Silva, N., Junqueira, V. C. A, Silveira, N. F. A., Taniwaki, M. H., Santos, R. F. S., \& Gomes, R. A. R. (2010). Manual de Métodos de Análise Microbiológica de Alimentos e Água. (4ª . Ed), São Paulo, Brasil: Livraria Varela.

Souza, P. S., Gonçalves, S. A., \& Dias, R. F. (2017). Aplicação Das Boas Práticas Por Manipuladores De Alimentos Em Pontos De Venda De Gelados Comestíveis. Higiene Alimentar, 31(268/269), 2-5.

Vasconcellos, J. S. P., \& Sangioni, L. A. (2017). Contribuição do ver-sus na formação do profissional médico-veterinário para o sistema único de saúde. Revista de Educação Continuada em Medicina Veterinária e Zootecnia do CRMV-SP, 15(1), 94-95.

Van Amson, G., Haracemiv, S. M. C., \& Masson, M. L. (2006). Levantamento de dados epidemiológicos relativos à ocorrências/surtos de doenças transmitidas por alimentos (DTAs) no estado do Paraná Brasil, no período de 1978 a 2000. Ciência e Agrotecnologia, 30(6), 1139-1145.

https://doi.org/10.1590/S1413-70542006000600016

Weber, C., \& Carrijo, K. F. (2018). Análise Microbiológica de Sorvete Expresso Comercializados em Uberlândia, Minas Gerais, Brasil. Enciclopédia Biosfera, $15(28), 58$.

http://dx.doi.org/10.18677/EnciBio_2018B6

World Health Organization [WHO] (2015). World Health Organization estimates of the global burden of foodborne diseases: foodborne disease burden epidemiology reference group 2007-2015. Geneva, Switzerland. 